\title{
Social Work and Family Therapy: Interdisciplinary Roots of Family Intervention
}

\begin{abstract}
Social work practice takes place between persons in families and other social institutions, such as schools, health systems, welfare systems or courts. Drawing from multi-disciplinary theoretical sources, the article brings together social work and family therapy to develop a contemporary model of social work practice with families. There are five generic principles of family systemic practice: 1) persons are inherently relational; 2) families have resilient strengths; 3) family life cycles proceed systemically generating relational tasks for family members; 4) repetitive family interaction generates relational structures; 5) cultures, as perceived by family members, are themselves in dynamic motion, necessitating a transcultural understanding of family interaction.
\end{abstract}

Keywords: social work, family therapy, family systemic therapy.

\section{Praca socjalna i terapia rodziny: interdyscyplinarne korzenie interwencji $w$ rodzinie}

\begin{abstract}
Abstrakt
Praktyka pracy socjalnej odbywa się pomiędzy członkami rodzin a innymi instytucjami społecznymi, takimi jak: szkoły, systemy opieki zdrowotnej, systemy opieki społecznej i sądy. Czerpiąc z multidyscyplinarnych źródeł teoretycznych, artykuł łączy pracę socjalną i terapię rodzinną $\mathrm{w}$ celu opracowania współczesnego modelu praktyki pracy socjalnej z rodzinami. Istnieje pięć ogólnych zasad systemowej praktyki rodzinnej: 1) osoby są z natury relacyjne; 2) rodziny mają siły rodzące sprężystość psychiczną; 3) cykle życia rodzinnego postępują systemowo, generując relacyjne zadania dla członków rodziny; 4) powtarzające się interakcje rodzinne generują struktury relacyjne; 5) kultury, postrzegane przez członków rodziny, znajdują się w stanie dynamicznego ruchu, co wymaga transkulturowego zrozumienia interakcji rodziny.
\end{abstract}

Słowa kluczowe: praca socjalna, terapia rodzin, systemowa terapia rodzin.

* Professor Emeritus, Loyola University Chicago, School of Social Work. 


\section{Introduction}

Families are the institutional core of every society. Across the globe families do up to $95 \%$ of all the caregiving, counseling, education, health care, and norm enforcement in their communities. Yet few families have the necessary preparation, skills and resources to address the myriad challenges they and their members face in today's complex and ever-changing societies. (Briar-Lawson 2016: 326). Families, undermined by the present social climate of individualism, often fail internally or give up their functions to the state. When families fail, welfare systems often attempt to take over family functions in an impossible attempt to do what families do best. In an endless circle of attribution-of-blame between families and welfare systems, the welfare systems fail as well. The reasons for this failure are clear. "Help" from the welfare system might consist of efforts to substitute for the family, to supplant it, to control it, to take over its unique tasks, rather than to support it. Most welfare systems or community institutions have little understanding of how to support families in their shared concerns. For obvious reasons, such efforts are destined to fail. And fail they do, as research studies show, whether of non-family based community intervention or of individually-focused intervention. Methods of intervention from the outside of the family need to be geared to the support of family functions and structure. Neither families nor outside social institutions can be effective without the other. For intervention to succeed there needs to be an understanding of the unique structures and functions of families, the relational tasks of persons in families, and the skills to intervene with that family, to assist its members to meet each other's relational needs and to solve problems. In the US, social work has a century of experience working with families. In the mid-1950's part of the professions of psychology and psychiatry joined with parts of social work to form a family therapy movement. We review in this paper the common theoretical frameworks, which emerged between these three disciplines over the following half century. We briefly reference the interdisciplinary theoretical work which eventually became the backbone of family therapy and of social work practice with families.

Families are the key to the development of sustainable models of social welfare. When society attempts to do for families what families can do naturally, it is very costly both to society and to families. And these efforts are inevitably ineffective. For example, in Lithuania under the previous welfare system deaf children were considered "defective" and sent to institutions, which were like warehouses. They were released at age 18 to become lost in society. Dr. Ruta Butkeviciene, a graduate of Vytautas Magnus University's social work program, made it her life's work to bring deaf children out of institutions into families. To do this, Dr. Butkeviciene needed to work with institutions for the deaf, with community schools, with families, and with the children themselves, each in relation to each other. 
As such, any social work with families is complex work, demanding skill - rigorous theoretical understanding and developed training. It cannot be taught simply in the classroom; it must also be learned in the field through a carefully coordinated and supervised field experience, working with real families, facing difficulties in real communities. To help families, social workers need to be able to walk delicately and carefully with family members through the complexity of family structure. They need to understand the many possible forms of family structure at different stages of family development. Family work demands a strengths-oriented perspective. It demands time for family members to discover their personal strengths, their strengths in each other, to become hopeful of change and to want to become involved in a change process. A social worker can only work with the permission, full understanding and cooperation of family members. Otherwise a family can easily become colonized by a social welfare system. When a family is colonized by the broader system, it will fight the system, or simply shut down and allow the state to take over. This would happen at great cost to the family, its members and to the broader society.

Family intervention has been of great importance in the century of development of social work in the United States (Richmond 1907, 1917). Family therapy, having its beginnings fifty years after the beginnings of social work, is only gradually translating competing methods approaches into common understandings of intervention (Nichols 2013). Many social workers now work, write and train others in the field of family therapy. Although social work has a far longer history of working with families than family therapy, some common understandings of the helping process are emerging. Without a good understanding of family interaction and a good foundation in intervention theory and in practice, it would be very difficult to be helpful to families. One common understanding is that family intervention should not primarily focus on correcting problems, but on building the strengths and capacities of families to be agents of their own development.

In addition to this common understanding, five integrative principles can be found in the literature and practice of social work and family therapy: 1) persons are inherently relational; 2) families can be resilient; 3) family life cycles proceed systemically and present interpersonal, relational tasks for family members; 4) repetitive family interaction creates relational structures, which can be mapped out, understood, and altered to better meet the intra/interpersonal needs of family members; 5) a transcultural basis for family interaction recognizes that cultures themselves, as experienced by family members, are in dynamic motion, present a range of alternatives, and can be modified to some degree. These basic practice concepts are developed in the book, Social Work with Families (Constable, Lee 2015).

One's beginning point in work with families must be an understanding of families and their members as interactive agents, as active subjects, not simply objects of help. Intervention methods are only useful insofar as they assist the interactions 
of family members, who themselves transform their relational structures. Family members cope, both as individual persons and together as a unit, with needs and stresses internal to the family as well as with their broader social and institutional environment. Family members respond to this complexity and balance their own internal change processes with the outside social situation. These tasks are difficult for family members, and they often need someone to help them in this.

Social Institutional Linkages. It is no accident that in working with families, social workers also work with (and often for) other social institutions, which are vital to family survival. These social institutional systems: health, education, work, welfare, family law and justice and religion, are all external to the family. They do their work best when they help the family to function without taking the family's place. They become social institutional anchors and societal guidance systems, meant to contribute to the family's ability to act effectively. Without these crucial institutional links, families would quickly experience stress and face breakdown. On the other hand, social institutions may also undermine families. When social institutions attempt to take over family functions, the family must either fight them, or become paralyzed and dissolve. Often families bear the brunt of what is essentially institutional failure (Ryan 1971). Nor can the institutions be successful without collaboration with families. They are essentially interdependent and this fact is a major rationale for social work practice.

Family Diversity with Common Functions. At present it is impossible to point to a "typical" family arrangement. Philip Cohen (2014a, 2014b) outlines the diversity of family forms found in the contemporary United States. Among 100 representative children: 34 may live with dual-earner, married parents, 22 live in a married, male breadwinner family, 23 with a single mother (only half of whom have ever married), 7 with a parent who cohabits with an unmarried partner, three with a single father, three with grandparents instead of parents and 8 in other categories (Cohen 2014b: 1). However, none of these diverse arrangements changes the essential tasks of families or the scope of social work with families. What is common to families, in their diversity, are certain social (and relational) tasks and functions:

- developing and ensuring solidarity among members;

- providing for the human development and differentiation of members;

- coping and helping members cope with the external world;

- coping with the special needs of members;

- defining themselves, their adequacy, and their strengths in an often confused environment that may devalue them;

- coping with their own unique developmental and structural needs, so as to perform the above tasks.

Family Life Cycles. It is through these tasks and functions that the family composes itself at different stages of its life cycles. These are the normal issues implicit in life-cycle changes. They are often quite difficult to manage (Constable, 
Lee 2015: 49-69). In addition, with certain family arrangements or with severe stresses, such as losing a family member, or having a child with special needs, the relational tasks for each member become more difficult and confusing. When the family faces breakdown, these tasks are often the point of entry for the social worker. Given this complexity, there will inevitably be confusion among family members about these tasks. Some of the social/institutional environment will be distinctly unhelpful to family members. If the family is to survive with resilience, it often needs time for a healing process to take place. It often needs healing persons in and outside the family to assist this process. If none of this healing takes place, the family could face paralysis or dissolution.

The Family Systems Framework. As social workers and family therapists attempted to conceptualize the complexity of family units in interaction, they developed the family systems framework. A system is a holistic, organized unit of independent transacting and mutually influencing parts within an identifiable environment (Siporin 1972a: 106). Systems theory allowed for the interaction of persons in family units, institutions, and whole communities to be better understood and mapped out (Hearn 1969; Hartman, Laird 1983). Using systems theory, interventions could be developed with several parts of the system, in their relations with each other and with the larger whole. Systems theory allowed social workers and family therapists to understand the complexity of what they were working with. With systems theory there came other assumptions, described in greater detail in the remainder of this paper.

Family Therapy. Family therapy emerged from different, competing practice methodologies, each particular family therapy methodology addressing one aspect of the family's functioning. There are six areas of family functioning around which different intervention methodologies developed: a) personal development and intrapersonal process, b) family communication and meanings, c) interpersonal and spiritual narratives and stories, d) family developmental processes, e) family structure or f) family environmental systems (Constable, Lee 2015: 10-14). As a consequence, each theory provides a somewhat different theoretical language to describe practice. In actual practice, skilled practitioners, working with real families, inevitably had to address all of these areas. Thus, family therapy approaches often became less a matter of mutually exclusionary dogma than emphasis. Moving between one level of family functioning to another as the situation and the assessment dictated, family practitioners often quietly used techniques from competing approaches in their work long before theoretical frameworks would begin to integrate these approaches in a common picture of family functioning. Most therapists, describing themselves as "integrative," would have a dominant, organizing, and central "home theory" that guided their overall perspective and understanding of the change process. They would import ("assimilate") (Messer 2001) selected techniques from other approaches into this home theory on a case-by-case basis (Gurman 2011: 287). 
Common Threads of Family Work. By the 1990s, both family therapy theory and practice were beginning to move toward some common understanding of all of the components of family interaction, bringing together different interventions at different levels of family functioning from the intrapersonal to the community systems levels (Bruenlin, Schwartz, Mac Kune-Karrer1992; Lebow 1997; Lebow 2003; Bruenlin and al. 2013; Pinsof and al. 2013). At the same time, a number of inclusive approaches to intervention were validated by random clinical trials (RCT) (Gurman 2011: 282). In one example, emotionally focused couple therapy (Johnson 2003; Johnson 2004), assimilated a variety of techniques into a well-organized, empirically validated, attachment theory and family systems base. In another example, broad-based family intervention, whether multisystemic therapy (Sheidow, Henggeler, Schoenwald 2003) or functional family therapy (Sexton, Alexander 2003; Sexton, Datchi 2014) assimilated community networking and work with all the family subsystems into an integrative, family systems base and repeatedly achieved robust, positive results on RCTs for complex problems of young people. These family therapy models are completely compatible with social work. Indeed, some of the actual experimental interventions were carried out by social workers.

International Research. By 2008 both family practice and research had come to the point where it was possible to identify and generalize a common thread of "family systemic therapy" from a large number of studies appearing in the international literature (German, Spanish, English, Mandarin Chinese). These studies addressed various problems of children, adolescents, and adults in families. The studies were sufficiently numerous and sophisticated, with large enough numbers of participants and adequate resources, to test the effectiveness of their interventions through random clinical trials (RCT's). The international selection criteria for these approaches required that: (1) They perceive behavior and mental symptoms within the context of the social systems people live in, (2) They focus on interpersonal relations and interactions, social constructions of realities, and the recursive causality between symptoms and interactions, (3) They include family members and other important persons (e.g., teachers, friends, professional helpers) directly and indirectly through specific interventions, such as systemic questioning and developing intervention hypotheses that included the entire family unit, and (4) they appreciate and use the client's perspectives on problems, resources, and preferred solutions.

International identification and testing of family systemic therapy is a significant watershed in the development of family practice. From 2008 to 2011, thirtyeight RCT studies of family intervention dealing with adult patients were identified in the international literature (Sydow et al. 2010). At the same time, forty-seven RCT studies of child and adolescent externalizing behavior (ADHD, conduct disorders, substance abuse) (Sydow et al. 2013), and thirty-eight RCT studies of child and adolescent internalizing and other behaviors (mood disorders, anxiety disor- 
ders, eating disorders, suicidality, etc.) (Retzlaff et al. 2013) were identified. The researchers compared each group through meta-analysis, studying the effectiveness of the interventions with the different problem categories. In these studies, for the broad majority of each group (34/38, 42/47, 33/38), systemic therapy was either significantly more efficacious than control groups without a systems oriented intervention, or systemic therapy was more efficacious than other evidencebased interventions. Such research is evidence that common, interdisciplinary orientations to family intervention, are now emerging in sufficient numbers to be identifiable, comparable, and deemed effective. Although social workers have a somewhat broader problem focus, which routinely includes the institutional environment (schools, health systems, courts, etc.), the general assumptions behind family systemic therapy are not different from social work with families. Family social workers have been doing this for some time. Each field of practice in schools, health systems, courts, welfare systems or in free-standing family practice, has its own distinct concerns and its own way of supporting family functioning (Constable, Lee 2015: 253-296).

\section{Principles of family systemic practice}

With this understanding of the distinctiveness of social work with families in different areas, we can return to our five integrative principles, and further outline their theoretical and research bases.

Persons are inherently relational. Family membership is a crucial part of a person's relational spectrum. The powerful, empirically-supported concept of the relational self has a long, diverse heritage in the work of William James (1981), George Herbert Mead (1934), Mary Richmond (1907, 1917), Harry Stack Sullivan (1938-1939), object relations theory (Greenberg, Mitchell 1983), membership theory (Falck 1976, 1988), self-psychology (Kohut 1977; Kernberg 1976), human development theories (Stern 1985; Fishbane 2001; McGoldrick, Shibusawa 2012), attachment theory (Ainsworth et al. 1978; Ainsworth 1973; Bowlby 1969; Donley 1993), particularly adult attachment theory (Sperling, Berman 1994; Mikulincer et al. 2002). An understanding of the relational person is fundamental to any further understanding of family interaction or intervention (Constable, Lee 2015: 26-43). This concept runs counter to popular concepts, either of the individualized self or the "over-socialized" self. In this sense an "individual" would denote a person with a more limited capacity for human relationships than a relational person.

Families can be resilient. The concept of family resilience provides a practical and observable way of understanding how very different families, with different structures, histories and cultural orientations, survive under stress. Often functioning under extreme conditions, the resilient family forges transformation and growth from adverse circumstances (Walsh 1999, 2003, 2012). In order for family 
members and the social worker to discover family resilience, there must be developed patterns of communication and interaction among family members, and there must be clear, family leadership. Resilient families are able to carry on through difficult and stressful situations. Cultural groups who have experienced extreme stress - such as slavery and subsequent discrimination, the Holocaust, deportation to Siberia, migration, or refugee flight - may carry with them the pain imposed by oppressive conditions, but also the qualities that have allowed them to survive in inhuman conditions. Polish families know a great deal about resilience. However, resilience is not simply a matter of one particular family structure or one person, but rather of how family members together learn to process relations with their internal and external environments. For families without effective patterns the effects of oppressive conditions could act to suppress the very qualities that would lead to survival. The resilient family becomes stronger in the midst of difficulty. It develops its meanings, interacts with its circumstances, and adapts creatively to these circumstances, preserving its own values. Family members are still able to communicate their needs and solve problems. The resilient family shows some ability to: approach adversity as a challenge shared by the whole family; normalize and contextualize distress; use adversity to gain a sense of its own coherence; make sense of how things have happened through causal or explanatory attributions; have a hopeful and optimistic bias; master the art of the possible; draw upon spiritual resources; develop flexibility and adaptability; develop its internal connections; use social and economic resources appropriately, communicate clearly and openly with each other; solve problems collaboratively (Walsh 1999, 2003, 2012; Constable, Lee 2015: 16-18).

Family life cycles proceed systemically and present intrapersonal and interpersonal, relational tasks for family members. Life cycle development and relational tasks provide the framework for family "work" and family intervention. At every particular stage of the family life cycle, there is an emotional process of transition (Constable, Lee 2015: 48-69). There are transactional patterns and relational systems typical to each stage. Implied in successful completion of these transitions are relational tasks for family members. These patterns and tasks are governed by the generational needs and issues characteristic of the stage (McGoldrick, Shibusawa 2012: 375-399; McGoldrick, Carter, Garcia-Preto 2010). There is a thrust toward fulfillment of these tasks and emergent needs. There is also a contrary thrust toward maintenance of aspects of an older relational system. One's previous life history and the relational environment will influence whether and how those needs are fulfilled and the tasks accomplished. Relational tasks have to do with interactive relationships with others that establish interpersonal patterns. They are carried out by family members in order to cope with what becomes necessary for the development of a workable family structure at a particular stage of development and in relation to a particular set of circumstances. 
Repetitive family interaction creates relational structures, which can be mapped out, understood and altered to better meet the emergent, intra/interpersonal needs of family members. Once recognized, relational structures are subject to interpersonal modification. Both symbolic interactionist social psychology, applied to family interaction (Turner 1970; Constable 1984a; Constable, Lee 2015: 72-104) and research on family interaction (Gottmann 1999), provide useful bases for understanding interaction and intervention. Since relational structure is mostly taken for granted by family members, the delicate and elaborate relational (and intentional) architecture of family interaction cannot easily be described and analyzed. This demands a systematic way of understanding and dealing with the validity of human subjective experience.

In order to understand and experience an otherwise elusive relational structure, post-modern family therapists enter the family system directly. They opt to take their path directly into the lived experience of a family to understand, participate in, and reshape their interaction. These therapists (White 2007; Beels 2009; Weingarten 1991, 2000, 2010, 2013) show a refreshing openness to the lived worlds of each family, and indeed of each person, with a more immediate description of one's experience and ways. Each family is like a world unto itself. To understand and join the family the social worker must learn a special type of humility and curiosity. Objectivity is joined to subjectivity in the "I" of the therapist. I must "enter" the family and experience it to understand it. When I, as a social worker become part of that family world, I am entering an alternate universe. Moreover, I can only enter the family as "I". To enter this world, we move from our abstract, relational language to a more personal language of "thicker" description (Ryle 1971). I am a bit like a distant relative or a visiting friend. At the same time, I remain a part of a broader world. I am not expected to suppress the world of my understandings and commitments as a professional.

In an effort to conceptualize social interaction, the symbolic interactionist school of social psychology (Mead 1934; Burr et al. 1979) has long worked on developing an understanding of mutual communication, intentionality, and mutual action in families. Ralph Turner (1970), in particular has developed a useful and theoretically cogent way of describing family interaction and its sources. All assume in one way or another that social relationships are created out of human experience and interaction. There are relations between the way people perceive reality, the way people act, their patterns of action, and the structures of relationships that they create. These structures in turn stabilize personal patterns and perceptions in a dense, complex recursive and reflexive relationship.

The interactional perspective is confirmed by a recent body of observational research on how couples actually behave with each other (Gottmann 1999; Gottman, Notarius 2002; Constable, Lee 2015: 77-83). Previous assumptions about couple interaction were constructed out of therapeutic experience with families, but they had little basis in observed interaction of families. Nor was there a focus on 
the complexity of multiple interrelationships. For three decades, John M. Gottman and others observed married couples' interaction as couples. On that basis, they began to form different hypotheses about couples' relationships. Because they focused primarily on interaction, their findings parallel in many ways the explanations of interaction provided by symbolic interactionist social psychology.

A transcultural basis for family interaction recognizes cultural differences within the reality that cultures, as processed by families, are themselves in dynamic motion. Cultures are not static In today's global society, rapid cultural change is taking place both within families and in their relationships with their surroundings. For example, Roma family members would have a dual cultural perspective: one oriented to their understandings of Roma culture, the other to their understanding of the broader culture, and where they place themselves in relation to these dynamic realities. A transcultural perspective is inherently a dynamic perspective that recognizes the reality that both families and society are in flux. It assumes that culture is dynamic and adaptive and that families often identify for themselves narrower beliefs than their actual capabilities. Family members often do not value their own resilience. The transcultural perspective assumes that all persons actively seek to construct secure relational bases, hoping to secure similar basic needs and relational goods (Constable, Lee 2015: 108-143).

However, there are also shifting concepts of what that relational base is, how it may be secured, and what is needed and expected in a culturally derived concept of relational justice. Without a sense of relational justice, family members could have limited commitment to the family unit. Family members often have different cultural understandings of relationships and different understandings of relational justice. Thus, it is challenging for families, experiencing cultural transition, to find their internal and external balances. The transcultural perspective integrates multicultural understandings with the picture of families and their members in the current changing environment of cultural meanings. Family members (and the social worker) take an active role accepting, adapting and redefining these meanings (Lee 1995; Constable, Lee 2015: 18).

\section{Summary}

All of these principles come together into a picture of family-centered social work practice for the 21st Century (Briar-Lawson 2016: 326). At present, one can find among social workers and family therapists an emergent, general understanding of the dynamics of family life cycles and family interaction necessary for a deeper understanding of family intervention. This developing understanding provides an opportunity for a shift to a deeper integration of the person-environment paradigm at the heart of social work with families, using the available theoretical language of family intervention. 


\section{References}

Ainsworth M. D. S. (1973) The development of infant-mother attachment in: Caldwell B. M., Ricciutti H. N. (eds.) "Review of child development research", vol. 3, Chicago, ILUniversity of Chicago Press: 1-94.

Ainsworth M. D. S., Bleher M. C., Waters E., Wall S. (1978) Patterns of attachment: A psychological study of the strange situation, Hillsdale, NJ Lawrence Erlbaum Associates.

Beels C. (2009) Some historical conditions of narrative work, "Family Process", 48 (3): 363-378.

Briar-Lawson K. (2016) Book Review: Social Work with Families: Content and Process (2nd ed.) "Journal of Teaching in Social Work", vol. 36, no. 3: 326-329.

Bowlby J. (1969) Attachment and loss, vol. 1: Attachment, New York, Basic Books.

Breunlin D. C., Pinsof W., Russell W., Lebow J. (2013) Integrative problem-centered metaframeworks therapy I: Core concepts and hypothesizing, "Family Process", 50 (3): 293-313.

Breunlin D. C., Schwartz R. C., Mac Kune-Karrer B. (1992) Metaframeworks: Transcending the models of family therapy, San Francisco, Jossey-Bass.

Burr W., Hill R., Nye F. I., Reiss I. L. (1979) Contemporary Theories about the Family, New York, The Free Press.

Cohen P. (2014a) The family: Diversity, inequality and social change, New York, W.W. Norton.

Cohen P. (2014b) Family diversity is the new normal for America's children, Council on Contemporary Families, September 4, 2014, https://contemporaryfamilies.org/thenew-normal/

Constable R., Lee D. B. (2015) Social work with families: Content and process, 2nd edition, Chicago, Lyceum Books.

Constable R. (1984a) Phenomenological foundations for the understanding of family interaction, "Social Service Review", 58 (1): 117-132.

Donley M. (1993) Attachment and the emotional unit, "Family Process", 32 (1): 3-30.

Falck H. S. (1988) Social work: The membership perspective, New York, Springer.

Falck H. S. (1976) Individualism and communalism: Two or one?, "Social Thought", 2 (3): $27-44$. 
Fishbane M. D. (2001) Relational narratives of the self, "Family Process", 40 (3): 273-293.

Gottman J. M. (1999) The marriage clinic, New York, Norton.

Gottman J. M., Notarius, C. I. (2002), Marital research in the 20th century and a research agenda for the 21st century, "Family Process", 41 (2): 159-198.

Greenberg J. R., Mitchell S. A. (1983) Object relations in psychoanalytic theory, Cambridge, MA Harvard University Press.

Gurman A. S. (2011) Couple therapy research and the practice of couple therapy: Can we talk?, "Family Process", 50 (3): 280-292.

Hartman A., Laird J. (1983) Family-centered social work practice, New York, Free Press.

Hearn G. (1969) The general systems approach: Contributions toward an holistic conception of social work, New York, Council on Social Work Education.

James W. (1981) Principles of psychology, vol. I, Cambridge, MA Harvard University Press.

Johnson S. (2004) The practice of emotionally focused couple therapy, New York, Brunner-Routledge.

Johnson S. (2003) Emotionally focused couples therapy: Empiricism and art in: T. L. Sexton, G. R. Weeks, M. S. Robbins, Handbook of Family Therapy, New York, BrunnerRoutledge: 263-280.

Kernberg O. F. (1976) Object relations theory and clinical psychoanalysis, New York, Jason Aronson.

Kohut H. (1977) The restoration of the self, New York, International Universities Press.

Lebow J. (1997) The integrative revolution in couple and family therapy, "Family Process", 36 (1).

Lebow J. (2003) Integrative approaches to couple and family therapy in: Sexton T. L., Weeks G. R., Robbins M. S., Handbook of family therapy, New York, BrunnerRoutledge: 201-225.

Lebow J. (2013) Programs for strengthening families, "Family Process", 52(3): 351-354.

Lebow J. (2014) Whither family therapy: Alive and flourishing amidst the changes, "Family Process", 53 (3): 365-366. 
Lee D. (1995) The Korean perspective on death and dying in: J. Parry, A. Ryan (eds.), A cross-cultural look at death, dying, and religion, Chicago, IL Nelson-Hall: 193-214.

McGoldrick M., Carter E., Garcia-Preto N. (2010) The expanded life cycle: Individual, family and social components, 4th ed. Boston, MA: Pearson.

McGoldrick M., Shibusawa T. (2012) The family life cycle in: Normal family processes, F. Walsh (ed.), 4th ed., New York, Guilford: 375-398.

Mead G. H. (1934) Mind, self and society, Chicago, IL University of Chicago Press.

Messer S. B. (ed.) (2001) Special issue on assimilative integration, "Journal of Psychotherapy Integration", 11(1).

Mikulincer M., Florian V., Cowan P. A., Cowan C. P. (2002) Attachment security in couple relationships: $A$ systemic model and its implications for family dynamics, "Family Process", 41 (3): 405-434.

Nichols M. P. (2013) Family therapy: Concepts and methods, 10th ed., Boston, MA Pearson, Boston, Allyn \& Bacon: 297-305.

Pinsof W. M., Breunlin D., Russell W., Lebow J. (2013) Integrative problem-solving metaframeworks therapy II: Planning, conversing and reading feedback, "Family Process", 50 (3): 314-336.

Retzlaff R., Sydow K. v., Beher S., Haun M. W., Schweitzer J. (2013) The efficacy of systemic therapy for internalizing and other disorders of childhood and adolescence: A systematic review of 38 randomized trials, "Family Process", 52 (4): 619-652.

Richmond M. (1917) Social diagnosis, New York, Sage.

Richmond M. (1907) The good neighbor, Philadelphia, Lippincott.

Ryan W. (1971) Blaming the victim, New York, Pantheon Books.

Ryle G. (1971) The thinking of thoughts: What is 'le penseur' doing? in: Collected Papers. London, UK, Hutchinson: 450-496.

Sexton T. L., Alexander J. F. (2003) Functional family therapy: A mature clinical model for working with at-risk adolescents and their families in: T. L. Sexton, G. R. Weeks, M. S. Robbins, Handbook of family therapy, New York, Brunner-Routledge: 323-350.

Sexton T. L., Datchi C. (2014) The development and evolution of family therapy research: Its impact on practice, current status, future directions, "Family Process", 53 (3): 434-444. 
Sheidow A. J., Henggeler S. W., Schoenwald S. K. (2003), Multisystemic therapy in: T. L. Sexton, G. R. Weeks, M. S. Robbins, Handbook of family therapy, New York, BrunnerRoutledge: 303-322.

Siporin M. (1972a) Introduction to social work practice, New York, Macmillan.

Siporin M. (1972b) Situational assessment and intervention, "Social Casework", 53: 91-109.

Sperling M. B., Berman W. H. (1994) Attachment in adults, New York, Guilford.

Stern D. N. (1985) The interpersonal world of the infant: A view from psychoanalysis and developmental psychology, New York, Basic Books.

Sullivan H. S. (1938-1939) A note on formulating the relationship of the individual and the group, "American Journal of Sociology", 4: 932-937.

Sydow K. V., Beher S., Schweitzer J., Retzlaff R. (2010), The efficacy of systemic therapy with adult patients: A meta-content analysis in 38 randomized controlled trials, "Family Process", 49 (4): 457-485.

Sydow K. V., Retzlaff R., Beher S., Haun M. W., Schweitzer J. (2013), The efficacy of systemic therapy for child and adolescent externalizing disorders: A systematic review of 47 RCT, "Family Process", 52 (4): 576-618.

Turner R. (1970) Family interaction, New York, Wiley.

Walsh F. (1999) Strengthening family resilience, New York, Guilford.

Walsh F. (2003) Family resilience: A framework for clinical practice, "Family Process", 42 (1): 1-18.

Walsh F. (2012) Family resilience: Strengths forged through adversity in: F. Walsh, Normal family processes, 4th ed., New York, Guilford: 399-427.

Weingarten K. (1991) The discourses of intimacy: Adding to a social constructionist and feminist view, "Family Process", 30: 285-306.

Weingarten K. (2000) Witnessing, wonder and hope, "Family Process", 39: 389-402.

Weingarten K. (2010) Reasonable hope: Construct, clinical applications and supports, "Family Process", 49 (1): 5-25.

Weingarten K. (2013) The "cruel radiance of what is": Helping couples live with chronic illness, "Family Process", 50(3).

White M. (2007) Maps of narrative practice, New York, Norton. 